\title{
Editorial
}

\section{FEDERAL FINANCING OF POSTSECONDARY EDUCATION AND RESEARCH: THE JOHNSON REPORT}

\author{
Ronald L. Watts, Queen's University
}

Universities in Canada are to-day at a critical turning point. Despite significant increases in enrolments and expansion in research effort during the past decade, and despite the expenditure of substantial public funds, there is a prevailing sense of stress and strain within our universities and colleges. At the root of this has been the imbalance between public objectives and the provision of financial resources. Since 1977, while enrolment in universities has increased by $27 \%$ and that in colleges by $36 \%$, support by our governments for the core operations of these institutions, expressed in constant dollar terms, has grown by only $2.5 \%$. During the same period the research demands upon our universities have grown substantially without corresponding increases in funding for the indirect costs of such research. Not surprisingly, there have been consequent severe strains and even limitations upon efforts to maintain student accessibility, quality of programs and research activity, and these are now beginning at last to attract some public concern.

Such pressures are by no means unique to Canada, but a major factor exacerbating the plight of our universities and colleges has been the character of the Established Programs Financing for Postsecondary Education (EPF/PSE) adopted in 1977 and the resultant malaise in federal-provincial relations concerning the financing of postsecondary education and research. A number of bodies such as the Association of Universities and Colleges of Canada (AUCC) and the Canadian Association of University Teachers (CAUT) have documented the underfunding of universities and have recommended remedial action. But particularly timely and judicious in its analysis and recommendations is the report prepared for the Secretary of State by Dr. A.W. Johnson, published in February under the title: Giving Greater Point and Purpose to the Federal Financing of Postsecondary Education and Research in Canada. Moreover, coming as it does from one who has had such an extensive experience as a practitioner in the realm of federal-provincial financial relations, including the establishment of the 1967 Postsecondary Education Financing Arrangements, this report deserves to be taken very seriously.

Johnson identifies six deficiencies arising from the current federal-provincial arrangements for financing postsecondary education and research as they have evolved since 1977. The first is the deficiency in finances provided to Canadian 
universities and colleges as illustrated by the drop in the proportion of the GNP made available by governments to these institutions for their core operations and by the steady decline in real expenditures per student during the period. The second is the lack of incentives in the current EPF/PSE arrangements for the provinces to increase their share of funding to match the increases in federal EPF/PSE transfers to the provinces. Consequently, the share of purely provincial financial support has been declining significantly, a trend which in turn has provided an incentive to federal politicians to restrict the EPF/PSE transfers since they do not appear to be linked by the provinces in any apparent way to the financing of universities and colleges. The third, is the resultant malaise in federal-provincial relations arising from the emergence of two conflicting perspectives concerning the purpose of the EPF/PSE transfers: the provinces insisting that the transfers are totally unconditional and unrelated to postsecondary education, and the federal government that there is at least a moral obligation on the part of the provinces to dedicate these fiscal transfers to postsecondary education without offsetting decreases in the growth of provincial grants to universities and colleges.

A fourth deficiency in Johnson's view is the inadequacy in funding for university research and particularly the indirect costs of that research at a time when it is generally realized that Canada's $R$ and $D$ effort must be substantially accelerated. The fifth deficiency with the current arrangements is that their focus has been primarily upon the goal of student accessibility, and that there have been few incentives and no mandated vehicle for concentrating resources for the creation of a few really world class centres of excellence in areas of importance to Canada's future. Finally, the sixth deficiency is the lack of self-induced reform and indeed the existence of incentives against reform inherent in the current arrangements.

Johnson's assessment of the deficiencies in the current arrangements is indeed valid. Experience has sadly confirmed the apprehensions which were expressed by the AUCC in 1977 when the previous incentives for provincial support were removed. The Johnson Report has tabulated the resulting substantial increase in the federal share of the provincial grants to universities and colleges from $69 \%$ in $1977-78$ to $80 \%$ in $1984-85$. Indeed in five of the ten provinces the federal EPF/PSE transfers represent more than $100 \%$ of the provincial grants to universities and colleges. The largest declines in "purely provincial shares" have occurred in British Columbia (25.4\%), Newfoundland (23.6\%), Manitoba (22.5\%) and Ontario (15\%). Johnson's point was reinforced forcefully only a few weeks after his report was released when Miller's new Minister of Colleges and Universities announced an increase in provincial grants to Ontario universities for 1985-86 explicitly several percentage points below the previously announced increase in federal PSE transfers for that year.

At the heart of this situation is the classical issue relating to fiscal transfers in any federal system: the need to balance the principle of provincial autonomy, i.e. avoiding the coercion of provinces by conditions attached to these transfers, with 
the principle of fiscal responsibility, i.e. ensuring that the government which has the unpleasant task of levying resources can satisfy itself that their expenditure is consistent with the purposes for which they have been levied. In the United States, traditionally the emphasis has been upon the latter principle with some modest exceptions during the past decade with the introduction of revenue sharing. In Canada, we have tended to emphasize the former principle at the expense of the latter, the documents supporting the 1977 PSE modifications going so far as to virtually abandon the principle of fiscal responsibility. The Johnson Report quite rightly argues for a better balance between the two principles, pointing to the long-term instability inherent in purely unconditional transfers which provide to the federal politicians little incentive for their continued maintenance.

The remedy which Johnson advocates is the conversion of the EPF/PSE transfers to the provinces into a system of "incentive grants". In reaching this conclusion, he rejects several frequently canvassed alternatives because of difficulties which outweigh their possible benefits.

One major approach for the federal government considered but rejected by Johnson is that of "getting off the field as a major player". This would involve an unequivocal withdrawal of the federal government from contributing to the core operations of Canada's universities and colleges through the EPF/PSE transfers to the provinces (currently totalling $\$ 4.2$ billion, composed of $\$ 2.1$ billion in transferred income taxes and $\$ 2.1$ billion in cash transfers), although the much smaller current contributions to student assistance through the Canada Student Loans Program and to research through the granting councils might be maintained. Such an approach was in fact advocated from time to time by some key members of the Trudeau cabinet in its latter years. The conversion of the EPF/PSE cash payments into purely unconditional transfers to the provinces would have little attraction to federal politicians concerned about "federal visibility" or about "accountability" for the expenditure of the taxes they levy. On the other hand, the use of the savings from discontinuing the EPF/PSE cash payments to the provinces in order to reduce the federal deficit is deceptively tempting, and the provision in the recent budget that the overall transfer payments to the provinces will be cut by $\$ 2$ billion annually by $1990-91$ appears threatening. If this proposed reduction were concentrated upon the PSE transfers, this could seriously deprive the universities and colleges of resources which are essential if they are to make their contribution to the national objectives of developing human resources and research. Furthermore, it would be certain to exacerbate federal-provincial friction at a time when it is the avowed intention of the new Mulroney government to improve federal-provincial relations.

A second possible general federal approach considered but rejected by Johnson is "getting off the present field and on to another one." This would involve withdrawing the current EPF/PSE cash payments to the provinces and substituting either a universal student grants or "vouchers" program or a massive increase in research grants to universities. The former variant would provide to all students a grant to cover the rise in fees resulting from the elimination of the federal transfers 
to the provinces for postsecondary education. From time to time, in recent years, this has been advocated in federal circles and also by many in the business community on the grounds that under such an arrangement the best instititions which are best able to attract students would benefit most. But Johnson identifies a number of problems in making the adjustment from the present system as well as technical and political problems related to the differential impact for provinces and for students of such arrangements, and concludes that the problems outweigh the advantages.

As to the variant of this approach substituting a massive increase in research grants, the five-fold increase in research grants that would be possible would certainly enable the establishment of some genuinely world class centres of excellence, but it would require a very substantial increase in tuition fees or provincial expenditure to compensate for the loss of the EPF/PSE cash payments in support of educational programs. When one considers the furor stirred in the media over one of the alternatives considered by the Bovey Commission that would have increased tuition fees in Ontario by some 50\% over five years, one can just imagine the public reaction to a federal proposal that would entail more than tripling the current tuition fees. Johnson is obviously correct in concluding that this option "is simply impractical".

The remedy which Johnson favours is that of the federal government "staying on the present playing field but with a change of rules". He proposes that the federal government offer to continue to use the present escalator for its PSE transfers (the rate of increase of GNP and population) for those provinces which increase grants to universities and colleges by the same amount. Within this upper limit, the federal government "would respect provincial priorities" by escalating the PSE transfers to each province only by the proportion by which that province increases its grants to the universities and colleges. This would, of course, create an "incentive" for provinces to move towards the maximum transfer level. Any federal funds saved due to provinces escalating at less than the maximum permissible level would be allocated instead to the federal research granting councils for additional support for research. Furthermore, to achieve a modest shift in emphasis towards sponsored research, Johnson advocates two steps: redirection from the $\$ 4.2$ billion in EPF/PSE transfers of $\$ 210$ million in order to finance the imputed indirect costs of the research currently being financed by the granting councils, and a five-year plan for escalating appropriations for the granting councils at a rate equal to 1.5 times the rate of growth of the GNP.

From among the possible alternatives, the Johnson Report provides for the federal and provincial governments the most realistic framework for consensus on modifications to the EPF/PSE arrangements. Interestingly, the Bovey Commission, in its chapter on federal-provincial relations, urged upon the Ontario government that it seek a harmonization of federal and provincial policies relating to financing of postsecondary education and research along rather similar lines. It is to be hoped, therefore, that not only the Secretary of State for whom the report was prepared, but other federal ministries and particularly the Ministry of Finance, 
and the provincial governments will give this report the very serious attention it deserves.

One area where the report is not as strong as it might be is on the need to develop world class centres of excellence. The diagnosis which points to the past tendency of both levels of government in Canada to concentrate almost exclusively upon the objective of student accessibility and the political difficulties of differentiating among institutions is quite correct. But the recommendation that "a blue-ribbon committee be named by the Government of Canada, composed of representatives of the public and private and university sectors, to propose to the government a vehicle, or vehicles, for the funding of a select number of world-class centres of excellence" leaves the issue largely unresolved. As members of the Bovey Commission found in reviewing the experience of other countries, the advantage of designating selected centres is often undermined by the bureaucratic and political processes entailed and the difficulty of correctly picking winners in advance. A more fruitful approach is likely to be one in which the evolution of centres of excellence is encouraged within a competitive context in which there are strong incentives based on rewards for institutional performance. For this purpose, the granting councils with revised mandates would be well suited.

There should be no mistake about it, the issues raised in the Johnson Report are extremely important not only for the future of postsecondary education and research in Canada, but for the country itself. In the long-term there is in fact a natural congruence between the fundamental goals of our universities and colleges and the goals of society. In our highly complex, rapidly changing, knowledgebased world, no society can be economically viable nor can it foster a great culture without a strong intellectual and cultural base. As Johnson himself points out, the advantages of educated human resources and of advanced research and technology which are typically required in such societies are not merely "advantages" but have become "imperatives". But universities and colleges in turn cannot fulfil their function of providing these benefits for society without the resources and culture of society to nourish them.

Given the congruence in the long-term priorities of the country and of the universities and colleges, involving their mutual interdependence and requiring mutual sensitivity to each other's particular needs, it is highly desirable that our governments together with our universities and colleges develop in partnership a conscious national strategy for the achievement of their mutual goals. Such a strategy should contain at least the following elements: (1) explicit public and governmental recognition of the vital importance of universities and colleges to national development; (2) continued primary emphasis by governments at both levels upon support for the core activities of higher education and research; (3) recognition that while the primary constitutional responsibility for education lies with the provinces, the provincial and federal governments have a shared interest in developing an adequate pool of highly qualified mindpower and in building a strong basic and applied research base through support for the core functions of the universities and colleges; (4) the harmonization of federal and provincial policies 
relating to postsecondary education and research; (5) the balancing of institutional autonomy and accountability in a way that ensures the vitality of the universities and colleges; (6) the encouragement of greater private sector support; (7) an emphasis upon excellence and adaptability within our institutions of higher education; (8) provision for diversity among our universities and colleges including incentives for the development of world-class centres of excellence; (9) fostering of student accessibility and mobility in the interests both of equality of opportunity and of the development to the full of Canada's human resources.

The task of making our universities and colleges effective as "institutions for national growth and vitality in the next century" is urgent. The Johnson Report provides a financial basis upon which the federal and provincial governments could together work in that direction.

\title{
LE FINANCEMENT FÉDÉRAL DE L'ENSEIGNEMENT POST- SECONDAIRE ET DE LA RECHERCHE: LE RAPPORT JOHNSON
}

\author{
Ronald L. Watts, Queen's University
}

Les universités canadiennes ont aujourd'hui atteint un point critique. En dépit de l'augmentation significative des inscriptions et de l'effort de recherche durant la dernière décennie; en dépit également de la part importante des fonds publics qui leur est attribuée, nos universités et collèges sont encore durement mis à l'épreuve. La cause en est le déséquilibre entre les objectifs publics et les ressources financières. Depuis 1977, alors que les populations étudiantes ont augmenté de $27 \%$ dans les universités et de $36 \%$ dans les collèges, le soutien de nos gouvernements pour le fonctionnement de ces institutions s'est accru seulement de 2,5\% (en dollars constants). Pendant la même période, les exigences de la recherche envers nos universités ont augmenté substantiellement sans pour cela qu'un accroissement du financement vienne couvrir les frais indirects de cette recherche. Il n'est donc pas surprenant que de sévères pressions et même des restrictions s'ensuivirent quant au maintien de l'accessibilité étudiante, à la qualité des programmes et aux activités de recherche. Cette situation commence enfin à capter quelque attention du public.

Ces pressions ne sont aucunement particulières au Canada; cependant, le principal responsable de la situation critique de nos universités et collèges est le Programme de soutien à l'enseignement postsecondaire (PSE/EPF), adopté en 1977 , et duquel a résulté un malaise dans les relations fédérales-provinciales au niveau du financement de l'enseignement postsecondaire et de la recherche. Certains organismes tels l'Association des universités et collèges du Canada (AUCC) et l'Association canadienne des professeurs d'universités (ACPU) ont étudié le sous-financement des universités et ont recommandé des solutions. Toutefois, le rapport de A.W. Johnson, préparé pour le Secrétaire d'Etat et publié 
en février sous le titre: "Pour une meilleure orientation du financement de l'enseignement postsecondaire et de la recherche par le gouvernement fédéral" est particulièrement à propos et présente des analyses et des recommandations judicieuses. De plus, provenant de quelqu'un qui a une si vaste expérience des relations fédérales-provinciales, y compris l'établissement, en 1967, des Règles de subvention de l'enseignement postsecondaire, ce rapport mérite d'être pris très au sérieux.

Des règles fédérales-provinciales actuelles de financement de l'enseignement postsecondaire et de la recherche, A.W. Johnson a identifié six lacunes qui se sont creusées depuis 1977. La première est le manque de financement des universités et collèges canadiens, comme l'illustrent la chute du pourcentage du PNB mis à la disposition de ces institutions par les gouvernements pour leur fonctionnement, et le déclin régulier des dépenses réelles par étudiant durant cette période. La deuxième est le manque de motivation des provinces à l'intérieur de ces règles, pour aligner leur part de financement sur les augmentations des transferts de fonds fédéraux du PSE/EPF aux provinces. Par conséquent, le soutien financier provincial a diminué de façon significative, tendance qui, à son tour, a incité les politiciens fédéraux à réduire les transferts de fonds du PSE/EPF puisque les provinces ne semblent apparemment pas les avoir reliés au financement des universités et collèges. La troisièmè est le malaise qui s'est installé dans les relations fédérales-provinciales et qui est le résultat de deux points de vue divergents concernant les objectifs des transferts de fonds du PSE. Ce sont: d'une part, l'insistance des provinces pour que les transferts soient tout à fait inconditionnels et non reliés à l'enseignement postsecondaire; d'autre part, le souhait du gouvernement fédéral que les provinces aient au moins l'obligation morale de consacrer ces transferts fiscaux à l'enseignement postsecondaire sans que ceux-ci servent de compensation aux baisses des subventions provinciales aux universités et collèges.

La quatrième lacune, selon M. Johnson, est la médiocrité du financement de la recherche universitaire, et particulièrement des frais indirects de cette recherche, à une époque où il est en général bien acquis que l'effort canadien pour la recherche et le développement doit être substantiellement soutenu. La cinquième lacune des règles actuelles réside dans le fait que l'accent est mis principalement sur l'accessibilité étudiante, et qu'il y a peu d'encouragement, et pas de véhicule mandaté en particulier, pour consacrer des ressources à la création de quelques centres de spécialisation de classe internationale dans des secteurs primordiaux pour l'avenir du Canada. Enfin, la sixième lacune est le manque d'auto-suggestion en matière de réforme et, bien sûr, l'existence de motifs contre la réforme inhérente aux règles actuelles.

L'évaluation des faiblesses de ces règles actuelles par $M$. Johnson est évidemment valable. L'expérience a malheureusement confirmé les craintes exprimées par l'AUCC en 1977 lorsque les incitations pour le soutien provincial furent supprimées. Le rapport Johnson fait ressortir l'augmentation substantielle de la part fédérale des subventions provinciales aux universités et collèges qui est 
passée de $69 \%$ en 1977-1978 à $80 \%$ en 1984-1985. Bien sûr, dans cinq des dix provinces, les transferts fédéraux du PSE/EPF représentent plus de $100 \%$ de la subvention provinciale aux universités et collèges. Les plus grandes baisses en part "purement provinciale" se sont produites en Colombie britannique $(25,4 \%)$, à Terre-Neuve $(23,6 \%)$, au Manitoba $(22,5 \%)$ et en Ontario (15\%). Les conclusions de A.W. Johnson ont été corroborées quelques semaines après la parution de ce rapport, lorsque le nouveau ministre des collèges et universités de l'Ontario du gouvernement Miller a annoncé une augmentation des subventions provinciales aux universités ontariennes pour 1985-1986. Celle-ci était en fait d'un pourcentage nettement inférieur à l'augmentation des transferts fédéraux du PSE pour cette année annoncée un peu plus tôt.

Au coeur de la question est le problème classique des transferts de budget au sein de tout système fédéral: la nécessité d'équilibrer le principe de l'autonomie provinciale (à savoir, ne pas assortir ces transferts de conditions contraignantes pour les provinces) et celui de la responsabilité financière (à savoir, une garantie que le gouvernement, qui a la tâche ingrate de prélever les taxes, redistribuera effectivement les ressources aux fins pour lesquelles elles ont été prélevées). Traditionnellement, les Etats-Unis s'en sont tenus à ce dernier principe; toutefois, une petite exception à la règle est apparue ces dix dernières années avec l'introduction du partage des revenus. Au Canada, nous avions tendance à mettre l'emphase sur le premier principe au détriment du second; les documents à l'appui des modifications du PSE de 1977 allaient même jusqu'à abandonner virtuellement le principe de responsabilité financière. A juste titre, le rapport Johnson défend un meilleur équilibre entre les deux principes, il attire l'attention sur l'instabilité à long terme inhérente à des transferts inconditionnels qui, de plus, encouragent peu les politiciens fédéraux à poursuivre leur soutien.

Comme solution, $\mathrm{M}$. Johnson recommande la conversion des transferts de fonds du PSE/EPF aux provinces en un système de "subventions d'encouragement". De cette façon, il élimine plusieurs avenues maintes fois débattues parce que les difficultés l'emportaient sur les bénéfices éventuels.

Une des principales approches, considérée par le gouvernement fédéral mais rejetée par M. Johnson, est celle du "retrait complet comme principal acteur". Ceci impliquerait de la part du gouvernement fédéral, un retrait non équivoque des contributions au fonctionnement des universités et collèges du Canada via les transferts de fonds du PSE/EPF aux provinces (totalisant actuellement 4,2 milliards, soit 2,1 milliards d'impôt redistribués et 2,1 milliards de liquidité), mais permettrait cependant de maintenir les moindres contributions à l'aide financière aux étudiants via le programme de prêts étudiants, et à la recherche via les conseils subventionnaires. Une telle approche avait en fait été de temps en temps préconisée par quelques personnages-clé des derniers temps du cabinet Trudeau. La conversion des paiements du PSE en transferts purement inconditionnels aux provinces aurait peu d'intérêt pour les politiciens soucieux de la "visibilité fédérale" ou de la "responsabilité" des dépenses des prélèvements fiscaux qu'ils effectuent. Par ailleurs, l'utilisation des économies réalisées par l'interruption des paiements du PSE/EPF aux provinces pour éponger le déficit fédéral est illusoire, 
et la prévision, dans le récent budget, que les transferts globaux aux provinces seront coupés de 2 milliards par an d'ici 1990-1991 semble assez effrayante. Si la majeure partie de ces réductions était concentrée sur les transferts du PSE, ceci pourrait sérieusement priver les universités et collèges des ressources essentielles à leur contribution aux objectifs nationaux de développement des ressources humaines et de la recherche. De plus, cela envenimerait certainement les relations fédérales-provinciales au moment où il est clair que le nouveau gouvernement Mulroney a justement l'intention de les améliorer.

Une deuxième approche globale possible pour le gouvernement fédéral, considérée mais également rejetée par $\mathrm{M}$. Johnson, est la tactique du "passage dans l'autre camp". Ceci impliquerait le retrait des paiements actuels du PSE/EPF aux provinces pour y substituer soit une subvention générale pour les étudiants ou programme de "bons", soit une augmentation massive des subventions de recherche aux universités. La variable précédente fournirait une subvention à tous les étudiants pour couvrir l'augmentation des frais de scolarité résultant de la cessation des transferts fédéraux aux provinces pour l'enseignement postsecondaire. Ces dernières années, ceci a été recommandé à quelques reprises dans les cercles fédéraux et par le monde des affaires, en alléguant que de cette façon, les meilleures institutions, les plus attrayantes pour les étudiants, en bénéficieraient le plus. Cependant, en faisant une adaptation au système actuel, M. Johnson a relevé un certain nombre de problèmes techniques et politiques reliés à l'impact différentiel de ces arrangements sur les provinces et sur les étudiants, et en a conclu que, là aussi, les inconvénients dépassaient de beaucoup les avantages.

Quant à l'autre variable de cette approche substituant un accroissement massif des subventions de recherche, l'augmentation des subventions de recherche à cinq volets qui serait possible permettrait certainement la création de quelques vrais centres de spécialisation, mais demanderait une augmentation importante des frais de scolarité ou des dépenses provinciales pour compenser la perte des paiements du PSE/EPF pour les programmes éducationnels. Si l'on en juge par la fureur des médias suscitée par une des solutions considérée par la Commission Bovey qui aurait augmenté de 50\% en 5 ans les frais de scolarité en Ontario, on peut imaginer la réaction du public à une proposition du fédéral qui aurait pour conséquence de tripler les frais de scolarité actuels. M. Johnson a tout à fait raison de conclure que cette option "est tout simplement impossible".

La solution favorisée par M. Johnson est que le gouvernement fédéral "reste dans le camp actuel mais change les règles du jeu". Il propose que le gouvernement fédéral offre de continuer à utiliser le système actuel pour ses transferts du PSE (le taux de croissance du PNB et de la population) pour les provinces qui augmentent leurs subventions aux universités et collèges dans les mêmes proportions. Ainsi, le gouvernement fédéral "respecterait les priorités provinciales" en basant les transferts à chaque province sur la proportion seulement dans laquelle celle-ci augmente ses subventions aux universités et collèges. Evidemment, ceci "motiverait" les provinces à s'orienter vers un transfert de fonds maximal. Tous les fonds fédéraux économisés sur le compte des provinces qui n'auront pas respecté le niveau maximal permissible, seraient alors 
alloués aux conseils fédéraux subventionnaires pour un soutien additionnel de la recherche. De plus, pour mettre une modeste emphase sur la recherche subventionnée, M. Johnson recommande deux étapes: des 4,2 milliards de dollars de transferts du PSE/EPF, réadministrer 210 millions pour couvrir les frais indirects de la recherche actuellement financés par les conseils subventionnaires, et l'élaboration d'un plan quinquennal pour les estimations des conseils subventionnaires équivalentes à 1,5 fois le taux de croissance du PNB.

Des solutions possibles, le rapport Johnson fournit aux gouvernements provinciaux et au fédéral le schéma le plus réaliste d'un consensus sur les modifications aux règles de transferts du PSE. Il est intéressant de noter que la Commission Bovey, dans son chapitre sur les relations fédérales-provinciales, pressait le gouvernement ontarien d'harmoniser les politiques fédérales et provinciales reliées au financement de l'enseignement postsecondaire et à la recherche. On espérait alors que non seulement le Secrétaire d'Etat, à qui le rapport était destiné, mais aussi les autres ministères fédéraux et particulièrement le ministère des Finances, et les gouvernements provinciaux accorderaient à ce rapport toute l'attention qu'il mérite.

Un domaine où le rapport n'est pas aussi fort qu'il aurait dû l'être est le développement des centres de spécialisation de classe internationale. Le bilan qui révèle la tendance passée des deux niveaux de gouvernement canadiens de se concentrer presque exclusivement sur les objectifs d'accessibilité étudiante ainsi que les difficultés politiques de différencier les institutions est tout à fait juste. La recommandation "qu'un super-comité, composé de représentants des secteurs publics, privés et universitaires, soit créé par le gouvernement du Canada pour lui proposer un ou des moyens de financer un nombre sélectionné de centres de spécialisation de classe internationale" est loin de résoudre la question. Comme l'ont noté les membres de la Commission Bovey en étudiant l'expérience d'autres pays, l'avantage de désigner des centres sélectionnés est souvent réduit par les divers processus bureaucratiques et politiques, et par la difficulté de choisir d'avance les gagnants. Une meilleure approche favoriserait plutôt l'évolution des centres de spécialisation dans un contexte compétitif où les récompenses seraient basées sur la performance institutionnelle. Dans ce cas, les conseils subventionnaires avec des mandats révisés seraient très utiles.

Il ne faut pas se leurrer, les questions soulevées dans le rapport Johnson sont extrêmement importantes, non seulement pour l'avenir de l'enseignement postsecondaire et de la recherche au Canada, mais pour le pays lui-même. A long terme en effet, une harmonie s'établira naturellement entre les objectifs fondamentaux de nos universités et collèges et ceux de la société. Dans l'univers qui est le nôtre actuellement, très complexe, changeant et basé sur le savoir, aucune société ne peut être économiquement viable, ni atteindre un haut degré de culture sans une solide base intellectuelle et culturelle. Comme $\mathrm{M}$. Johnson le recommande lui-même, une forte mise en valeur des ressources humaines, une recherche et une technologie très avancées ne sont plus des "avantages" mais bien des "impératifs" vitaux. Cependant, les universités et les collèges ne peuvent remplir leur mission 
ni fournir ces bénéfices à la société sans les ressources et la culture de cette société pour les alimenter.

Considérant l'harmonie des priorités à long terme impliquant l'interdépendance et la sensibilité aux besoins mutuels de nos gouvernements, nos universités et nos collèges, il est hautement souhaitable qu'ensemble, ils développent une stratégie nationale pour atteindre leurs buts respectifs. Cette stratégie devrait au moins comporter les éléments suivants:

1. La reconnaissance explicite du public et du gouvernment de l'importance vitale des universités et collèges pour le développement national.

2. Un effort soutenu des deux niveaux de gouvernement pour financer le fonctionnement de l'enseignement supérieur et de la recherche.

3. La reconnaissance de la responsabilité constitutionnelle des provinces en matière d'éducation, et du fait que les gouvernements provinciaux et le fédéral ont un intérêt partagé à la mise en valeur de ressources humaines hautement qualifiées et à l'instauration de solides bases de recherche appliquée et fondamentale par des supports au fonctionnement des universités et collèges.

4. L'harmonisation des politiques fédérales et provinciales en matière d'enseignement postsecondaire et de recherche.

5. L'équilibre entre l'autonomie institutionnelle et le sentiment de responsabilité pour assurer la vitalité des universités et collèges.

6. La stimulation d'un meilleur soutien du secteur privé.

7. L'emphase sur l'excellence et l'adaptation de nos institutions d'enseignement supérieur.

8. Une place pour la diversité dans nos universités et collèges y compris des incitations au développement de centres de spécialisation de classe internationale.

9. Le développement de l'accessibilité et de la mobilité étudiantes, dans l'intérêt à la fois de l'égalité des chances et du développement total des ressources humaines canadiennes.

Il est urgent de faire de nos universités et collèges des "institutions utiles à la croissance et à la vitalité nationales pour le siècle à venir." Le rapport Johnson fournit une base financière à laquelle les gouvernements provinciaux et fédéral pourraient oeuvrer ensemble. 